\title{
An Exploratory Study on Integrating Sustainability Aspects During the Acquisition of Production Equipment
}

\author{
Md Hasibul ISLAM ${ }^{\mathrm{a}, 1}$, Zuhara CHAVEZ and Monica BELLGRAN ${ }^{\mathrm{a}}$ \\ ${ }^{a}$ KTH Royal Institute of Technology, Department of Sustainable Production \\ Development, SE-151 36 Södertälje, Sweden
}

\begin{abstract}
Production equipment such as machines have crucial impact on the overall performance of production operations in manufacturing industries, since there is a strong correlation between the machines and working conditions and performance on the shop floor. Well designed production equipment has the potential to achieve economic gain by reducing the disturbances during the operational phase, to fulfill environmental commitment by reducing emissions and resources consumption and utility, and to increase employee satisfaction ensuring safety and good ergonomics. Therefore, when acquiring production equipment it is important to consider different sustainability aspects relevant to its usage during the operational phase. This study aims at exploring the critical features of production equipment to facilitate different practices in the context of sustainable production operational system, and how manufacturing companies are considering sustainability aspects when acquiring production equipment. The data has been collected based on a literature study, interviews conducted in different manufacturing companies located in Sweden, attending group discussion sessions, and reviewing machines' technical regulation guidelines. Some of the critical features identified are error proofing, setup time, one-piece flow, automatic generation of required data, reduction of energy and resource consumption, together with worker's health and safety, etc. The data indicates that companies specify different features of machines based on the requirements of operational performance and these features are aligned with different lean techniques, green practice, and safety issues. However, during acquisition process of production equipment the environmental issues are still not prioritized yet compared to lean and safety aspects. Budget constraint, insufficient information of the whole life cycle costing and lack of innovation from the equipment suppliers' side are exampled of major barriers for acquiring more environment-friendly production equipment.
\end{abstract}

Keywords. Sustainable production equipment, acquisition, lean, green, machine

\section{Introduction}

At present, awareness about sustainability has become burgeoning consent among customers, and most forward-looking organizations put it as their main goal to stay competitive in business [1]. Companies are becoming more concerned to reduce the carbon footprint of their products due to pressure from regulatory authorities on climate change. One of the goals set by the UN regarding sustainable development is to ensure sustainable consumption and production pattern, and within this goal, one of the targets

${ }^{1}$ Corresponding Author. mhisla@kth.se 
is to encourage companies to adopt sustainable practices [2]. Apart from this, the European Union has set a goal to reduce the greenhouse gas emission level by $40 \%$ than its level in 1990. In these contexts, companies are required to adopt sustainable practices to comply with the requirements.

As sustainability concepts are related to the triple bottom line- economic, environmental and social impact, companies need to look for tools and techniques that could help them achieve their goals on all three aspects. In order to achieve economic success, many manufacturing companies use different tools and techniques derived from Lean philosophy. Emerging green manufacturing techniques with lean philosophy, companies can achieve their goal in economic and socio-environmental sectors [3].

In order to facilitate the implementation of Lean and green manufacturing techniques, it is important to design the production equipment or machines in accordance with the requirements of the production system $[4,5]$. It is the machines that transform the material from one state to another state to make the desired products. The machine requires operators to control its functions, energy and other resources to run, and regular maintenance activities to increase its reliability. Well-designed production equipment has the potential to improve the overall equipment efficiency by increasing availability, performance and desired quality rate. In addition, incorporating also green machining techniques, such as designing for less consumption of lubricant or cutting fluid, energyefficient control panels, and the reduction of emissions and waste, means that machines could play a vital role to achieve the company's socio-environmental targets.

Therefore, the research presented in this paper aims at focusing on how to consider the different sustainability aspects of the production operation phase during the acquisition phase of production equipment or machines. This paper will mainly addresses the following research questions:

RQ-1: What critical features of the production equipment or machines impact the manufacturing practices in the context of a sustainable production operation system?

RQ-2: How are manufacturing companies considering sustainability aspects when acquiring production equipment or machines?

To the best of our knowledge, the above questions have not been fully addressed in previous research work. Therefore, this paper will focus on addressing the mentioned research gap. This research mainly focuses on the production equipment user's perspective, for instance, manufacturing companies that use different production equipment or machines to manufacture their products. Machine manufacturer's or suppliers' perspective is not considered here.

\section{Literature Review}

\subsection{The production equipment acquisition process}

The acquisition process of production equipment could be related to industrialization, process improvement, capital investment [6]. The acquisition of production equipment includes several activities such as planning, designing of equipment, purchasing, transportation, installation, testing, training, and other administrative issues [7, 8]. Companies acquire new machines in the production sites based on several business needs, such as increasing capacity, improving efficiency, flexibility or other means [7]. The acquisition of machines could vary from purchasing a single machine to launching a new production line or even building an entirely new 
manufacturing plant. Figure-1 which represents the lifecycle stages of process development projects [9] has been selected as suitable for this study to exemplify the acquisition process.

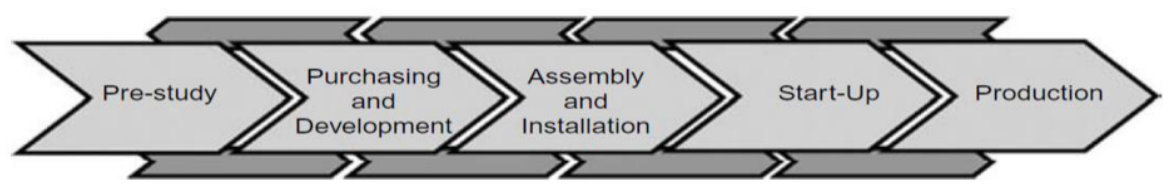

Figure 1. Life cycle stages of a process development project [9].

\subsection{Sustainable production system}

Based on this paper's research context it is important to define what sort of sustainability aspects will be considered, relevant to the production system. There are several ways to define sustainability in the manufacturing context. For example, the US Department of Commerce defines sustainable production as "the creation of manufactured products that use processes that minimize negative environmental impacts, conserve energy and natural resources, are safe for employees, communities, and consumers and are economically sound" [10]. The Lowell Center for Sustainable Production defines sustainable production as "the creation of goods and services using processes and systems that are non-polluting, conserving of energy and natural resources, economically viable, safe and healthful for workers, communities, and consumers, socially and creatively rewarding for all working people" [10]. Both definitions can be related to the triple bottom line (3BL) concept of sustainability concepts referring to the fact that businesses should achieve sustainable strategy in three dimensions, i.e. in the economy, environmental and social perspective [11, 12].

Economic sustainability mainly aims at the financial success of the company. In order to maintain economic sustainability companies adopt different types of techniques from Lean philosophy or company-specific X-production systems [13]. Research shows that different lean techniques, such as JIT, kaizen, TQM, Six Sigma, TPM, contribute to achieving sustainable economic development as it reduces operational cost, inventory cost and environmental cost $[14,15,16]$. Apart from the lean philosophy, the Industry 4.0 concept has drawn the attention of industries and researchers due to its potential impact on sustainable manufacturing operations [17]. Application of practices within the Industry 4.0 concept has immense potential to assist lean manufacturing [18] as well as to transform the operational process towards a more sustainable one. There are several elements within the broad dimension of Industry 4.0, such as big data analysis techniques, autonomous robots, cyber-physical production systems, simulation [19].

Environmental sustainability mainly refers to the efficient usage of resources, less emission, and wastes to the environment, reduction of energy and other resources [1]. In order to achieve environmental sustainability, companies have adopted several green practices, such as energy \& resource-efficient production [20], green performance map [21] or life cycle assessment [22]. In addition, implementing lean practices improve companies' environmental performance as well [23].

Social sustainability concerns mostly societal related benefits such as creating more job opportunities, equality, health and safety issues dealing with product usage, service, and manufacturing sites [1]. There are different social practices, such as employee 
education and training, volunteering and philanthropy, corporate health and safety system, which could improve companies' social sustainability [24, 25].

According to Wang et al. [1] practicing lean, green and social practices individually improves the overall sustainability performance of the companies. As part of the literature study, the practices presented in tablel are selected in relation to the sustainability aspects that are found suitable for the purpose of the research presented in this paper.

Some of the practices have an impact on multiple dimensions of the sustainability aspects, i.e. it could be both economic, environmental and/or societal. For instance, energy efficiency or less resource consumption has a direct impact on both environmental and economic aspects of companies' performance. However, in this research paper, the effect on multiple dimensions has not been considered.

Table 1. Practices related to sustainability considered in this study

\begin{tabular}{|l|l|}
\hline Sustainability aspects & Practices \\
\hline Economic & $\begin{array}{l}\text { Lean } \\
\text { Industry 4.0 }\end{array}$ \\
\hline Environment & Cleaner production \\
\hline Social & Health \& Safety \\
\hline
\end{tabular}

\subsection{Production equipment and sustainable production system}

Based on the research conducted by Yusup et al. [26] it has been found that there is a strong correlation between lean and clean production practices, and the selection of production equipment affects the improvement of the working condition in shop-floor that facilitate the lean and clean production practice. Another research done by Iranmanesh et al. [27] revealed that production equipment has a significant impact on sustainable performance, and the authors also claim that having lean culture moderates the impact of production equipment on sustainable performance. Therefore, welldesigned production equipment has the potential to improve the company's overall sustainable performance, especially during the production operations phase.

Previous researches also highlighted to design machines in accordance with the demand for lean production system to facilitate implementing Lean [4], considering ecodesign concept [28] or green and lean principles/requirements [5]. Therefore, in the acquisition process of production equipment or machines, it is important to consider different features (which could be temred as critical features or factors also) of production equipment that will facilitate the implementation of different production practices as mentioned in table- 1 .

\section{Research methodology}

The research has adopted the exploratory research concept, since it helps to understand the current situation and problems and leads to further research opportunities [29]. In addition, exploratory research is suitable to conduct when the problem is not well understood and remains an uncertainty, for instance, due to lack of sufficient research [29], which is the case of the research scope presented here. Data is collected through a literature study and by conducting interviews at different types of manufacturing industries in Sweden as part of the explorative research. The first research question is answered based on the literature study. The literature articles were searched in two 
databases- Scopus and Web of Science Group, using combination of different wordsproduction/manufacturing, equipment/machine, sustainability/ lean/green/eco, within the atricle title, keywords and abstract. In addition, snowball sampling method was used to look for articles as well that is relevant to the first research question.

The second research question is answered based on empirical data collected in the conducted interviews, by attending industrial team meetings (where access was granted) and by reviewing companies' specific documents related to the acquisition of production equipment. The interviews were conducted in a semi-structured way and by face to face meetings. The semi-structured interview as a technique can provide more insightful information, flexibility and is suitable for understanding complex problems [30] and was therefore selected. For these reasons, this approach has been used to answer research question two.

In order to reduce the biases of data, respondents from different functions and strategic and operational levels were selected. In addition to collecting data through interviews, the company's specific equipment purchasing guidelines or specifications, (when available) were analyzed in order to understand which and how sustainability aspects were specified in their standardized working procedure. Table-2 presents details of the companies and collected data.

Table 2. Company-specific data collection detail

\begin{tabular}{|c|c|c|c|c|c|}
\hline $\begin{array}{l}\text { Company } \\
\text { Name }\end{array}$ & $\begin{array}{l}\text { Company } \\
\text { type }\end{array}$ & $\begin{array}{l}\text { Number of } \\
\text { interviewees }\end{array}$ & $\begin{array}{l}\text { Interviewees } \\
\text { working area }\end{array}$ & $\begin{array}{l}\text { Collected } \\
\text { documents }\end{array}$ & $\begin{array}{l}\text { Group } \\
\text { meeting } \\
\text { attended }\end{array}$ \\
\hline $\mathbf{A}$ & Automotive & 2 & $\begin{array}{l}\text { Purchasing } \\
\text { Production }\end{array}$ & $\begin{array}{l}\text { Machine } \\
\text { specification } \\
\text { guideline }\end{array}$ & - \\
\hline B & Pharmaceutical & 3 & $\begin{array}{l}\text { Purchasing } \\
\text { Purchasing } \\
\text { Lean coach }\end{array}$ & $\begin{array}{l}\text { Machine } \\
\text { specification } \\
\text { template, quotations }\end{array}$ & 3 \\
\hline $\mathbf{C}$ & $\begin{array}{l}\text { Construction } \\
\text { Equipment }\end{array}$ & 1 & Energy & - & - \\
\hline D & Automotive & 1 & Purchasing & - & - \\
\hline
\end{tabular}

For case company-A, interviews were made with two professionals working in an investment project and in one specific production area respectively. In addition, the company had developed a standard machine specification regulation guideline that is sent to machine suppliers with quotations and this documentation was studied by the researchers as part of the data collection.

For case company-B, interviews were made with three professionals who worked with capital investment and Lean. In addition, the company's machine specification generation template and several quotations were analyzed.

For case company-C, the respondent had been working on improving the energy consumption rate of the plant for the last five years and was currently, managing kaizen activities with the purpose of saving energy associated with the production machines. In addition, the respondent actively participates in machine investment projects. It implies that the interviewee had relevant and extensive knowledge of the company's working procedure related to the production machine/equipment acquisition process as well as an overview of the overall production system design process.

For case company-D, the interviewee had been working with purchasing production equipment for the last twelve years and had been leading different capital investment 
projects for several years. Hence, the interviewee was found having sufficient knowledge of the company's working procedure when acquiring production equipment.

As the interview was on semi-structured basis, each interviewee was asked at first to tell briefly about the companies' current production system design model, how do they defined machine specifications, who defines it and who are involved in the defining process. Later, they were asked if different sustainability aspects during the operational phase is considered when defining machine specification, and to be more specific what sort of lean and green factors are considered. Finally, they were asked about determining factors when selecting a supplier. Based on their response further discussion was carried out as part of the data collection.

\section{Results}

\subsection{Critical features of production equipment}

This section will mainly state different factors or specifications for machines and production equipment that could impact different common practices of a sustainable production system which is related to the first research question. Based on the literature study, in table-3, a list of critical features of production equipment have been selected which are categorized based on the sustainability related practices identified in table- 1 .

Table 3. List of critical features of different practices related to production equipment, identified in literature

\begin{tabular}{|c|c|c|c|}
\hline $\begin{array}{l}\text { Sustainability } \\
\text { aspects }\end{array}$ & Practices & $\begin{array}{l}\text { Factors/ Features of production } \\
\text { equipment }\end{array}$ & References \\
\hline \multirow[t]{19}{*}{ Economy } & Lean & Easy and reliable maintenance & {$[31],[32]$} \\
\hline & & Support one-piece flow & {$[31]$} \\
\hline & & Error proofing & {$[31],[33]$} \\
\hline & & Easy to control & [31] \\
\hline & & Support Standardization & [31] \\
\hline & & Minimum tool change time/setup time & {$[31],[32]$} \\
\hline & & Easy to clean & [31] \\
\hline & & Easy to operate by operators & {$[31]$} \\
\hline & & Minimum scrap rate & {$[31]$} \\
\hline & & Desired quality of product & {$[31],[32]$} \\
\hline & & Flexible operations & {$[31],[32]$} \\
\hline & & Being portable & [31] \\
\hline & & Support visualization & {$[31]$} \\
\hline & & Low complexity of equipment & [32] \\
\hline & & Low inventory level of products & {$[32]$} \\
\hline & Industry 4.0 & Data generation features & [19] \\
\hline & & Communicate with other machines & {$[17]$} \\
\hline & & Working autonomously & [19] \\
\hline & & Self-adjustment in response to the error & [19] \\
\hline \multirow[t]{6}{*}{ Environment } & Clean production & Energy efficient & {$[31],[34]$} \\
\hline & & Less Emission & [34] \\
\hline & & Less Chemical Hazard & {$[34]$} \\
\hline & & Less waste of resources & [34] \\
\hline & & Reusable frames & [35] \\
\hline & & Design for upgrading & [36] \\
\hline \multirow[t]{2}{*}{ Social } & Health \& safety & Safety to operators & {$[31]$} \\
\hline & & Ergonomics features & [34] \\
\hline
\end{tabular}


Table-3 represents different features that affect the mentioned practices- lean, industry 4.0 , cleaner production, health $\&$ safety in terms of different sustainability aspects which can be considered as the answer of the first research question.

\subsection{Practices in manufacturing industry}

This section represents the data collected from different industries mentioned in table-2 aligned with the second research question the data is further discussed in section4.

\subsubsection{Case company- $A$}

This company is one of the leading companies in the automotive industry. They have their own model for capital investment for production equipment and have also developed and implemented their own lean production system defined as the $\mathrm{X}$ production system [13] in order to be more competitive in business. The empirical findings indicate that while acquiring production equipment the needs from the shop floor (production phase) are considered and translated into functional requirements like desired cycle time, highest desired quality, short changeover time, reliability, etc.

The company has developed written guidelines on technical regulations for production equipment and machine design. The guideline is 118 pages in total and it has different sections such as requirements about dimension, painting, electric system, automation, and control system, lubrication system, safety and work environment, etc. This guideline is sent to equipment suppliers with quotations so that the equipment is delivered according to the regulations. In these regulations, different types of safety and ergonomics issues are mentioned, such as a) emergency stop systems, b) device for disconnection of energy, c) ergonomic standards maintaining EN 614-1:2006+A1:2009 and EN 614-2+A1:2008 standards, d) machining chip, cutting fluid, oil, lubricant should not leak out on the floor, etc. In addition, the guideline specifies the energy efficiency issues as well to thrive suppliers to design more energy-efficient solutions. Some examples of design specifications for energy-efficiency mentioned in the document are a) design machines that stop automatically if no processing is required, b) the machine could be turned off and restarted on the same functional level, c) programmable start for warming up, among others. This indicates that the company has in place a "best practice" in place aiming at acquiring energy-efficient production equipment.

However, interviewers mentioned that a common fact is that environmental issues need to be economically justified. For example, if suppliers offer more resource-efficient machines that involve additional costs, the economic saving from reducing resource consumption during the operation phase must justify the extra investment to be considered.

\subsubsection{Case company-B:}

This company is a pharmaceutical manufacturing company. Recently, the company has developed standardization for acquisition process of production equipment. In addition, the company has initiated Green Kaizen activities in several production lines to improve the resource efficiency level. The company has also adopted lean practices to improve its production process and performance. The empirical findings indicate that while purchasing equipment or doing investment, health $\&$ safety aspects are top priority. It is because pharmaceutical companies' production process deals with different types of 
chemicals that could involve risks regarding workers' safety. Apart from this, while acquiring new production lines or equipment, the company considers different functional requirements that cover lean aspects such as improving OEE, changeover time, quality, etc. However, the respondents in the study stated that at this moment, environmental issues were not being highly prioritized when specifying requirements and even in some of the cases this was not specified in the purchasing order. In the group meeting sessions, attendants also discussion environmental aspects to be even more included in their capital investment model.

In the machine specification template, which is used during the acquisition process, different instructions related to safety aspects were specified such as; a) compliance with EU CE marking regulation, b) all lubricants to be specified with a safety data sheet, c) exhaust air containing oil should be directed via an oil-separation filter, d) emergency stops should be included.

On the aspect of collaborating with the suppliers of the machines and production equipment, respondents highlighted that there was a lack of competency from the suppliers' side on offering energy-efficient machines. According to one of the respondents: "I would be happy if equipment suppliers come up with new environmentally friendly solutions, however, it has never happened."

\subsubsection{Case company-C:}

Case company $\mathrm{C}$ manufactures components for the automotive industry. One of the manufacturing plants within the company has adopted a practice to reduce the energy consumption of the production equipment. Several Kaizen events have been performed to increase awareness among operators about energy consumption during the change over time of the machines. In addition, this practice included utilizing data of the energy consumption of different machines during the whole operational time. By using this data, they expected to find suitable improvements related to the machines and their spindle speed and power consumption etc. to use for specifying requirements when purchasing production equipment.

According to a respondent: "Right now the purchasing department specifies that machines should be energy efficient, however, at this moment there is no specific way to say how much energy efficient it should be, for instance, the power consumption or kWh of machines are not being specified when purchasing equipment." This statement indicates that the company is trying to increase the energy efficiency level of the production equipment.

\subsubsection{Case company-D:}

The manufacturing company, here called case D, is also one of the leading companies within the automotive industry in Sweden. According to the respondent's opinion, when purchasing production equipment different lean factors like high OEE, low changeover time, easy to control, etc. were considered based on the requirements from the shop-floor. In some cases, simulation was also used to define machine parameters. When designing a production system, professionals from different departments, such as production, maintenance, health \& safety, etc were involved. Safety issues were prioritized as the company's culture was to develop products considering safety issues first for users, and this practice was followed also during manufacturing operations according to the respondent. Regarding the environmental aspects, the company had been working on achieving environment-friendly production systems, i.e. 
thus tried to purchase equipment with environment-friendly solutions. According to the respondent: "We have already reached a certain level of the energy-efficient production system, however, achieving higher energy efficiency level, costs much more which becomes infeasible in economic perspective."

However, the company did not have a fixed machine specification guideline like company-A and the respondent mentioned that it was customized based on the functional requirements of the specific machines to be purchased.

\section{Discussion}

Based on the literature search to answer first research question, it was found that similar study had been done to identify critical factors in production equipment focusing on only Lean practice [31]. However, critical factors or specifications of production equipment considering triple bottom line of sustainability aspects were missing in the exisitng literature. Therefore, list of critical features presented in table-3 tried to fulfill the gap. However, it needs to be noted that, the factors presented in this paper may not cover all the factors related to different sustainability features.

Based on the initial results of the interview, it has been observed that when purchasing production equipment, the companies put the functional requirements of machines, such as cycle time, changeover time, reliability, etc., based on shopfloor's production competency which can be related to different operational principles of lean theory. It is unlikely that for each machine all of the features mentioned in table- 3 are considered, rathers the features are defined based on the requirements from shopfloor and operational KPIs.

Regarding the social aspects, operators' safety issues are also prioritized in the companies when specifying the requirements of the production equipment. In the machine specification guideline for company-A and company-B, different ergonomics and safety standards related to EU legislation have been mentioned. Respondents from all companies agreed that health and safety issues were prioritized at the best of the companies standard and practice, though there was still room for improvements.

Regarding the environmental aspect of sustainability, several energy-efficient features (mentioned in section 3.2.1) were found in the machine specification guide of company-A so that machine suppliers could add those features into their products. For company-B, in the machine specification template and in some quotations it was mentioned that machines needed to be energy efficient, but not how this should be made as like company-A. The interview data from company-C and company-D also indicates a similar result, i.e. that companies are trying to adopt equipment considering environmental issues, however, there is a lack of methodology or tool that aids companies on incorporating this issue in the machine specification. Apart from this, in practice when taking a decision of selecting equipment supplier the economic factor is still dominant. To be specific, for example, if equipment suppliers claim that their equipment is more energy-efficient, in that case, the money saved by consuming less energy during the operation phase must compensate for the extra investment in the long run. Respondents from all of the company's agreed that it has never happened that they invest extra for considering more environmentally friendly aspects in machine and production equipment, and in case of a tight budget or a constraint situation the environmental aspects is often ignored. This behavior can be supported by the research conducted by Wiederhold et al. [37] where they mentioned limited budget and the high 
price of the products as major barriers to purchasing green products. Therefore, based on the data, it indicates that companies are still not prioritizing environmental issues before price..

Regarding the budget constraint, the respondent in company-C argued that budget is an issue; however, for the last couple of years they have saved some budget in operational cost by reducing the energy consumption on the infrastructural level at the plant, and that saving could be utilized for upgrading production equipment. This management practice supports the finding of Golini et al. [38] where they emphasized decentralized strategic decision making in terms of sustainability aspects.

Respondents also highlighted that innovation from the suppliers' side was not as expected on offering machines with environmental-friendly solutions. In addition, the companies often failed to get enough information about the accurate life cycle costing of the machine from machine suppliers. Due to a lack of sufficient information about life cycle costing, sometimes they failed to make the right investment decisions. Lack of sufficient reliable data from suppliers is one of the major barriers for calculating life cycle costing [39].

In relation to the above discussed barriers, Quinn et al. [40] proposed that specifying environmental occupational health and safety issues in the checklist, while purchasing equipment and resources, creates awareness to employees and also sets specifications in the purchase order. It encourages the equipment supplier to be more environmental in product design and to consider safety and ergonomic issues in their products. For case company-A, different safety and environmental issues were specified in the purchase order, however, there was no clear indication if specifying these requirements was motivating suppliers to design more environment-friendly machines.

\section{Conclusion, Implication \& Future Research}

Based on the study, the list of critical factors represented in table-3, identified from the literature study, could be considered as a base for developing guideline for machine specification when acquiring production equipment in order to facilitate the sustainability aspects of the production operation phase.

The empirical data indicates that in the acquisition process of new production equipment when sending quotations to equipment suppliers, companies usually define machines' specifications based on shopfloors' requirements in order to facilitate the operational targets or production competency. In most of the cases, these specifications are aligned with different features related to lean techniques and safety aspects listed in table-3, and in some cases, the environmental issues are also specified. However, compared to economic and safety issues, environmental ones are still not prioritized prioritized. Budget constraint, insufficient information for the whole life cycle costing and lack of innovation from equipment suppliers' side are mentioned as major barriers for acquiring environment-friendly production equipment.

Regarding the practical implication, the list of critical factors could be utilized as a checklist to define specifications before purchasing production equipment. In addition, there is a possibility to score the current state of production equipment based on these critical factors and consider the score to generate specifications when upgrading or changing the machines. In addition, this research also pointed out that there is a great need to emphasize green aspects when designing a production system (where the machines are an important part), and mentioned some challenges when not prioritizing 
the green aspect. Companies need to overcome these challenges in order to increase the environmental sustainability.

Further research should be devoted to studying the incorporation of circular economy and digitalization aspects in designing machines and defining machine and equipment specifications. Furthermore, knowledge needs to be developed to develop critical factors more extensively and develop tools or methods for assessing the current state of production equipment in terms of sustainability. In addition, research efforts are necessary to understand how companies could be motivated to prioritize environmental aspects on the same level of economic aspects during the acquisition process. More empirical studies are required to see the effect of considering different sustainability factors during equipment design and analyze the economic impact.

\section{References:}

[1] Z. Wang, N. Subramanian, A. Gunasekaran, M. D. Abdulrahman and C. Liu, Composite sustainable manufacturing practice and performance framework: Chinese auto-parts suppliers' perspective, International Journal of Production Economics, vol. 170, 2015, pp. 219-233.

[2] United Nations, 2019, The Sustainable Development Goals Report, [Online]. Available: https://unstats.un.org/sdgs/report/2019/The-Sustainable-Development-Goals-Report-2019.pdf

[3] R. D. L. Júnior, A. O. Nunes, L. B. M. Costa and D. A. L. Silva, Creating value with less impact: Lean, green and eco-efficiency in a metalworking industry towards a cleaner production, Journal of cleaner production, vol. 196, 2018, pp. 517-534.

[4] C. Herrmann et al., An environmental perspective on Lean Production, In: Manufacturing Systems and Technologies for the New Frontier, Springer, London, 2008, pp. 83-88.

[5] L. Smith and P. Ball, Steps towards sustainable manufacturing through modelling material, energy and waste flows, International Journal of Production Economics, vol. 140, 2012, pp. 227-238.

[6] Q. Yang, Remanufacturing Versus New Acquisition of Production Equipment: Definitions and Decisionmaking Checklist, Mälardalen University, 2014.

[7] M. Bellgran and E. K. Säfsten, Production development: design and operation of production systems, Springer Science \& Business Media, 2009

[8] H. P. Barringer et al., Life-cycle cost tutorials, In: Fourth International Conference on Process Plant Reliability, Gulf Publishing Company, 1995.

[9] D. Rönnberg-Sjödin, A lifecycle perspective on buyer-supplier collaboration in process development projects, Journal of Manufacturing Technology Management, vol. 24, 2013, pp. 235-256.

[10] M. A. Rosen and H. A. Kishawy, Sustainable manufacturing and design: Concepts, practices and needs, Sustainability, vol. 4, 2012, pp. 154-174.

[11] C. Gimenez, V. Sierra and J. Rodon, Sustainable operations: Their impact on the triple bottom line, International Journal of Production Economics, vol. 140, 2012, pp. 149-159.

[12] J. Elkington and I. H. Rowlands, Cannibals with forks: the triple bottom line of 21 st century business, Alternatives Journal, vol. 25, 1999, pp. 42.

[13] T. H. Netland and A. Aspelund, Company-specific Production Systems and Competitive Advantage : A resource-based view on the Volvo Production System, International Journal of Operations \& Production Management, vol. 33, 2013, pp. 1511-1531.

[14] M. G. Yang, P. Hong and S. B. Modi, Impact of lean manufacturing and environmental management on business performance: An empirical study of manufacturing firms, International Journal of Production Economics, vol. 129, 2011, pp. 251-261.

[15] P. J. Martínez-Jurado and J. Moyano-Fuentes, Lean management, supply chain management and sustainability: a literature review, Journal of Cleaner Production, vol.85, 2014, pp. 134-150.

[16] K. Govindan, S. G. Azevedo, H. Carvalho and V. Cruz-Machado, Impact of supply chain management practices on sustainability, Journal of Cleaner Production, vol. 85, 2014, pp. 212-225.

[17] T. Stock and G. Seliger, Opportunities of sustainable manufacturing in industry 4.0, In: Procedia Cirp, vol. 40, pp. 536-541.

[18] A. Sanders, C. Elangeswaran and J. P. Wulfsberg, Industry 4.0 implies lean manufacturing: Research activities in industry 4.0 function as enablers for lean manufacturing, Journal of Industrial Engineering and Management, vol. 9, 2016, pp. 811-833. 
[19] M. Rüßmann, M. Lorenz, P. Gerbert, M. Waldner, J. Justus, P. Engel and M. Harnisch, Industry 4.0: The future of productivity and growth in manufacturing industries, The Boston Consulting Group, vol. 9, 2015, pp 54-89. https://doi.org/10.1007/s12599-014-0334-4

[20] J. R. Duflou, et al., Towards energy and resource efficient manufacturing: A processes and systems approach, CIRP Annals - Manufacturing Technology, vol. 61, 2012, pp. 587-609.

[21] K. Romvall, M. Kurdve, M. Bellgran and J. Wictorsson, Globalized Solutions for Sustainability in Manufacturing, In: Proceedings of the 18th CIRP International Conference on Life Cycle Engineering, 2011, pp. 353-358.

[22] A. K. Bhetja and R. Babbar, Study of green supply chain management in the Indian manufacturing industries: a literature review cum an analytical approach for the measurement of performance, International Journal of Computational Engineering and Management, vol. 13, 2011, pp. 84-99.

[23] S. Hajmohammad, S. Vachon, R. D. Klassen and I. Gavronski, Reprint of Lean management and supply management: their role in green practices and performance, Journal of Cleaner Production, vol. 56, 2013, pp. 86-93.

[24] A. Warhurst, Sustainability indicators and sustainability performance management, Mining, Minerals and Sustainable Development [MMSD] project report, vol. 43, 2002, pp. 1-129.

[25] R. Lozano and D. Huisingh, Inter-linking issues and dimensions in sustainability reporting, Journal of Cleaner Production, vol. 19, 2011, pp. 99-107.

[26] M. Z. Yusup, W. H. Wan Mahmood, M. R. Salleh and A. S. Mohd Yusof, The Adoption of Lean and Cleaner Production - A Preliminary Study for Malaysia Manufacturing Industry, In: Applied Mechanics and Materials, 2014, vol. 660, pp. 949-953.

[27] M. Iranmanesh, S. Zailani, S. Hyun, M. H. Ali and K. Kim, Impact of Lean Manufacturing Practices on Firms' Sustainable Performance: Lean Culture as a Moderator, Sustainability, vol. 11, 2019, pp. 1112.

[28] A. K. Jönbrink, H. L. Norrblom, and M. Zackrisson, Ekodesign: praktisk vägledning, Swerea IVF AB, 2011.

[29] B. van Wyk, Research design and methods Part I, University of Western Cape, 2012

[30] F. Fylan, Semi-structured interviewing, In J. Miles P. Gilbert: A handbook of research methods for clinical and health psychology, Oxford university press, 2005, pp. 65-78.

[31] Z. Mohammadi, S. Shahbazi and M. Kurdve, Critical Factors in Designing of Lean and Green Equipment, In: Cambridge International Manufacturing Symposium (CIM conference), Cambridge University, UK, 2014.

[32] D. K. Edwards, Practical guidelines for lean manufacturing equipment, Production and Inventory Management Journal, vol. 37, 1996, pp. 51.

[33] J. Flinchbaugh and A. Carlino, The hitchhiker's guide to lean: Lessons from the road, Society of Manufacturing Engineers, 2006

[34] J. Bruch, C. Rösiö, M. Kurdve, M. Bengtsson, A. Granlund, E. Dahlquist and L. Swanström, Development of Robust Production Equipment: A guide to strong collaboration between users and suppliers, 2016.

[35] B. Peukert, M. Saoji and E. Uhlmann, An Evaluation of Building Sets Designed for Modular Machine Tool Structures to Support Sustainable Manufacturing, In: Procedia CIRP, 2015, vol. 26, pp. 612-617.

[36] M. Mörtl, Design for upgrading of machines and production processes: a guidline based on actual demands of industry and sustainable design, In: DS 31: Proceedings of ICED 03, the 14th International Conference on Engineering Design, Stockholm, 2003, pp. 409-410.

[37] M. Wiederhold and L. F. Martinez, Ethical consumer behaviour in Germany: The attitude-behaviour gap in the green apparel industry, International Journal of Consumer Studies, vol. 42, 2018, pp. 419-429.

[38] R. Golini, A. Longoni and R. Cagliano, Developing sustainability in global manufacturing networks: The role of site competence on sustainability performance, International Journal of Production Economics, vol. 147, 2014, pp. 448-459.

[39] S. Kunttu, O. Kettunen and T. Välisalo, Life Cycle Cost Calculations as the Means for Value Communication in Networks, In J. Vesalainen et al.: Practices for Network Management In Search of Collaborative Advantage, Palgrave Macmillan, Cham, 2017, pp. 205-217.

[40] M. M. Quinn, D. Kriebel, K. Geiser and R. Moure-Eraso, Sustainable production: A proposed strategy for the work environment, American Journal of Industrial Medicine, vol. 34, 1998, pp. 297-304. 